\title{
Antibody responses to Haemophilus influenzae type $b$ conjugate vaccine in sickle cell disease
}

\author{
D Goldblatt, $M$ Johnson, J Evans
}

\begin{abstract}
Objective - To investigate the immunogenicity of Haemophilus influenzae type b (Hib) conjugate vaccines in children with sickle cell disease.

Design-Open study.

Setting-Haemoglobinopathy clinic.

Subjects-Children with homozygous haemoglobin SS disease (HbSS), sickle haemoglobin $C$ disease (HbSC), and sickle- $\beta^{\circ}$ thalassaemia disease (HbS$\beta$ Thal).
\end{abstract}

Interventions-Children over the age of 2 years received a single dose of Hib-tetanus toxoid conjugate vaccine (PRP-T).

Main outcome measures - Antibody response to Hib polysaccharide (PRP) approximately one month after vaccination.

Results - 77 children over the age of 2 years were studied, 55 with HbSS, 16 with HbSC, and six with HbS- $\beta$ Thal. Before vaccination, $44 \%$ had anti-PRP IgG titres less than the level associated with long term protection $(1.0 \mu \mathrm{g} / \mathrm{ml})$. After a single dose of PRP-T all children mounted an antibody titre > $1 \mu \mathrm{g} / \mathrm{ml}$. Geometric mean anti-PRP IgG titre achieved postvaccination $(45.2 \mu \mathrm{g} / \mathrm{ml} 95 \%$ confidence interval (CI) 31.6 to 64.8) was comparable to that of a healthy population. Children with HbSC, however, had a significantly higher antibody titre postvaccination $(91.1 \mu \mathrm{g} / \mathrm{ml}$; 95\% CI 32.7 to 254.4) than the children with HbSS (36.7 $\mu \mathrm{g} / \mathrm{ml}$; 95\% CI 25.1 to 52.9).

Conclusions - Children with a diagnosis of sickle cell disease who are over the age of 2 years make a vigorous antibody response to a single dose of PRP-T vaccine and hence we suggest unimmunised individuals in this group should receive a single dose of a $\mathrm{Hib}$ conjugate vaccine.

(Arch Dis Child 1996;75:159-161)

Keywords: Haemophilus influenzae type b, sickle cell disease, vaccine.

Department of Haematology and Oncology, Host Defence Unit, The Hospital For Sick Children NHS Trust, London M Johnson $\mathrm{J}$ Evans

Correspondence to Dr David Goldblatt, Institute of Child Health, 30 Guilford of Child Health, 30 Guilford

Accepted 21 May 1996 homozygous sickle cell disease (HbSS), who have been estimated to have a 500-1800-fold increased risk of pneumococcal meningitis and a case fatality rate for pneumococcal septicae-
Children with sickle cell disease are at increased risk of infection with bacteria that contain a polysaccharide capsule. The most mia of $44 \%$, compared to $2-17 \%$ in otherwise healthy infants. ${ }^{1}$ While the major pathogen in this group is Streptococcus pneumoniae, penicillin prophylaxis has proved successful in reducing the incidence of invasive $S$ pneumoniae infection. ${ }^{2}$ A second important pathogen is Haemophilus influenzae type b (Hib) which accounts for a disproportionately large amount of infection in children of all ages with sickle cell disease compared to their healthy counterparts. ${ }^{34}$ This risk has been estimated as $1 / 81$ person years for children $<5$ years of age with sickle cell disease, which is two to three times higher than the risk in normal children under 5 years of age. ${ }^{5}$ Within sickle cell disease the risk for invasive bacterial infection varies according to the form of the disease, those with HbSS. being at higher risk than those with sickle haemoglobin $\mathrm{C}$ disease (HbSC) ${ }^{6-8}$ While splenic function is thought to be important in protecting individuals from invasive bacterial infection, the susceptibility of children with sickle cell disease to such infections cannot be attributed solely to splenic dysfunction and remains poorly understood. Before the introduction of conjugated $\mathrm{Hib}$ vaccines, pure $\mathrm{Hib}$ capsular polysaccharide vaccines were evaluated in children with sickle cell disease. They were shown to be non-immunogenic in children under the age of 18 months and poorly immunogenic in those from 18 months to 5 years. ' Hib conjugate vaccines, in contrast, have been shown to be highly immunogenic in healthy infants as young as 2 months of age ${ }^{10}$ and their introduction into the routine infant immunisation programme has resulted in a dramatic decline in the incidence of invasive $\mathrm{Hib}$ disease in the UK. ${ }^{11}$

As a result of the increased risk of bacterial infection in sickle cell disease, immunisation to protect children from both $S$ pneumoniae and Hib infection is recommended in the USA by the American Academy of Pediatrics and the Centers for Disease Control, Atlanta. ${ }^{12}$ However, the UK Department of Health makes no mention of sickle cell disease in its list of recommendations for $\mathrm{Hib}$ conjugate vaccine, but does recommend pneumococcal vaccination in this group. ${ }^{13}$ Routine Hib conjugate vaccination introduced in the $U \mathrm{~K}$ in 1992 was targeted to children below 5 years of age; hence children born before 1988, including those with sickle cell disease, will have remained unimmunised.

The aim of this study was to establish baseline anti-Hib polysaccharide antibody titres in a group of children with sickle cell disease, to evaluate the immunogenicity of a single dose of

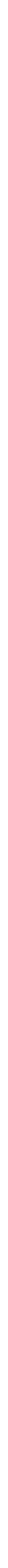


Table 1 Geometric mean anti-Haemophilus influenzae type b (Hib) polyribosyl phosphate IgG titres post Hib-tetanus toxoid conjugate vaccination

\begin{tabular}{llll}
\hline & \multicolumn{2}{l}{ Geometric mean anti-PRP IgG $(\mu g / m l)$} & $(95 \%$ confidence intervals) \\
\cline { 2 - 4 } & $H b S S$ & $H b S C$ & HbS- $\beta$ Thal \\
\hline No & 55 & 16 & 6 \\
Pre & $0.92(0.85$ to 1.29$)$ & $1.18(0.63$ to 2.18$)$ & $1.19(0.26$ to 5.55$)$ \\
Post & $36.7^{\star}(25.1$ to 52.9$)$ & $91.12^{\star}(32.7$ to 254.4$)$ & $34.82(9.41$ to 128$)$ \\
\hline
\end{tabular}

Children are divided into those with homozygous sickle cell disease (HbSS), sickle-haemoglobin $\mathrm{C}$ disease (HbSC), and sickle- $\beta^{\circ}$ thalassemia disease (HbS- $\beta$ Thal). Anti-polyribosylphosphate (PRP) IgG levels were measured by enzyme linked immunosorbent assay in serum obtained 4-8 weeks postimmunisation.

^ Student's $t$ test: HbSS $v$ HbSC, $\mathrm{p}=0.026$.

an Hib conjugate vaccine in such children, and to compare the vaccine immunogenicity in children with different forms of sickle cell disease whose risk varies for invasive Hib disease.

\section{Methods}

PATIENT POPULATION

Children over 2 years of age with the diagnosis of $\mathrm{HbSS}, \mathrm{HbSC}$, or sickle- $\beta^{\circ}$ thalassaemia disease (HbS- $\beta$ Thal) were eligible for this study and were recruited from a population of children attending a sickle cell disease clinic at the Queen Elizabeth Hospital, Hackney, London between January 1993 and January 1994. Ethics approval for the study was obtained locally and informed written consent was obtained for each participant. Children who had been given previous Hib vaccines were excluded from the study, as were children under the age of 2 years who received their vaccination from general practitioners. Immunisation was delayed if children were febrile at the time of consultation.

\section{PROCEDURES}

Study participants received $0.5 \mathrm{ml}$ intramuscularly of a licensed Hib-tetanus toxoid conjugate vaccine (ActHib, Merieux UK). Parents were asked to keep a record of adverse events for one week following immunisation. Information on adverse events was either telephoned to the study nurse or obtained at the follow up visit. Serum samples were obtained before and between one and two months after immunisation and stored at $-70^{\circ} \mathrm{C}$ before analysis.

\section{SEROLOGICAL STUDIES}

Total antibody to PRP was assayed by enzyme linked immunosorbent assay (ELISA) as previously described. ${ }^{14}$ Antibody levels in the unknown serum were derived from the standard curve and expressed as $\mu \mathrm{g} / \mathrm{ml}$. The standard curve was derived from an internal standard serum calibrated against a reference serum obtained from the US Food and Drug Administration Office of Biologics, Research and Review (kindly supplied by $\mathrm{Dr}$ Carl Frasch), which contains $60.9 \mu \mathrm{g} / \mathrm{ml}$ of antiPRP IgG. The assay was compared with a similar assay at another centre (Oxford, UK [see 10]) and the correlation between the two assays for pairs of infant sera was 0.97 (H Griffiths, personal communication). Accepted titres relating to short and long term protection from invasive $\mathrm{Hib}$ disease are 0.15 and 1.0 $\mu \mathrm{g} / \mathrm{ml}$ respectively. ${ }^{15}$
STATISTICAL ANALYSIS

Antibody concentrations below $0.15 \mu \mathrm{g} / \mathrm{ml}$ were assigned a value of $0.08 \mu \mathrm{g} / \mathrm{ml}$ for the purpose of calculation. Differences between groups were analysed by mean of a Student's $t$ test on normalised data.

\section{Results}

Seventy seven children were studied (44 males, 33 females), of whom 55 had HbSS, 16 had $\mathrm{HbSC}$, and six had HbS- $\beta$ Thal. The mean age of the children studied was 8.65 years (range 2 to 16.42 years). The mean age for $\mathrm{HbSS}$ children was 8.75 years ( 2 to 16.42 ), for $\mathrm{HbSC}$ 7.9 years (2.08 to 15.75$)$, and for $\mathrm{HbS}-\beta$ Thal 9.21 years ( 6.25 to 14.66$)$. The majority of the children in the study were either of West African $(n=43)$ or Afro-Caribbean origin ( $n=$ 30).

The vaccine was well tolerated, with no immediate reactions. Only one vaccinee reported swelling and erythema at the site of the injection lasting for more than 48 hours.

Analysis of the prevaccination titre of anti-PRP IgG for the group as a whole showed that $12 \%(9 / 77)$ had an antibody titre $\leqslant 0.15$ $\mu \mathrm{g} / \mathrm{ml}, 32 \%(25 / 77)$ had an antibody titre $>0.15$ and $\leqslant 1.0 \mu \mathrm{g} / \mathrm{ml}$, while $55 \%$ (43/77) had an antibody titre $>1.0 \mu \mathrm{g} / \mathrm{ml}$. Following vaccination all study participants achieved a titre of anti-PRP antibody of $>1 \mu \mathrm{g} / \mathrm{ml}$. Analysis of the correlation between age and the prevaccination anti-PRP titre showed there to be no positive correlation $\left(r^{2}=0.02\right)$ for the group as a whole. In addition there was no positive correlation between the age of the vaccinee and the magnitude of the postvaccination responses $\left(r^{2}=0.01\right)$.

The geometric mean prevaccination antibody titre for the group as a whole was 1.0 $\mu \mathrm{g} / \mathrm{ml}$ (95\% confidence interval (CI) 0.75 to $1.34)$ and postvaccination, $45.2 \mu \mathrm{g} / \mathrm{ml}(95 \% \mathrm{CI}$ 31.6 to 64.8 ). The geometric mean titre after vaccination was independent of ethnic background $(p=0.42)$. Interesting differences were noted for the subgroups of sickle cell disease (table 1). Before vaccination there was no difference between the geometric mean antibody titres for the three groups. However, after vaccination children with $\mathrm{HbSC}$ had a higher geometric mean antibody titre than the children with both HbS- $\beta$ Thal $(p=0.1)$ and HbSS $(p=0.026)$. All groups, however, achieved mean levels well above the accepted minimum protective level.

\section{Discussion}

Children with sickle cell disease are unduly susceptible to infection with encapsulated bacteria, and young children with sickle cell disease are particularly at risk. ${ }^{35}$ The susceptibility of this group stratifies according to the type of sickle cell disease. Children with HbSS are most at risk, while those with $\mathrm{HbSC}$ appear to be much less susceptible. ${ }^{6-8}$ The basis for this difference is poorly understood, although it is clear that splenic function is lost earlier in HbSS than in HbSC. ${ }^{16}$ Fatal infections with encapsulated organisms in children with 
HbSC have, however, been described ${ }^{417}$ and their risk of invasive infection is said to be higher than those of the general population. ${ }^{45}$

Forty four per cent of the children in this study had a prevaccination titre of $<1.0$ $\mu \mathrm{g} / \mathrm{ml}$, the level associated with long term protection in the healthy population. While the risk of invasive $\mathrm{Hib}$ infection in the healthy population declines sharply with age and is rare after the age of 5 , it is likely that children with sickle cell disease remain at risk, especially if splenic function is compromised. Half the children in this study were therefor potentially at risk of infection on the basis of their antibody titres. Following a single dose of PRP-T, $100 \%$ had a level of anti-PRP IgG $>1.0 \mu \mathrm{g} / \mathrm{ml}$ and the postvaccination geometric mean titre for the group as a whole was very close to that published for healthy adults following Hibconjugate vaccine ${ }^{18}$ and to that published for children with sickle cell disease resident in the USA. ${ }^{19} 20$

Several studies have sought a difference in the immunogenicity of conjugate vaccines in $\mathrm{HbSS}$ versus $\mathrm{HbSC}$, although the numbers of children studied have been small and no significant differences have been detected. Frank et al compared the immunogenicity of conjugated versus unconjugated PRP. ${ }^{21}$ While $46 \mathrm{HbSS}$ and $18 \mathrm{HbSC}$ patients were studied, the groups were divided to compare the different vaccine formulations and no statistical differences were detected between the two groups. Recently, Marcinak et al in a follow up study of antibody persistence following Hibconjugate vaccination, have been unable to detect a difference in the GMT of anti-PRP titres in children with $\mathrm{HbSS}$ compared to $\mathrm{Hb}$ SC disease nor any difference in the rate of anti-PRP antibody decline. ${ }^{22}$

In our study, children with a diagnosis of HbSC mounted a significantly higher anti-PRP IgG response than those with $\mathrm{HbSS}$. While this higher titre correlates with a reduced susceptibility to invasive $\mathrm{Hib}$ disease in $\mathrm{HbSC}$ compared to HbSS, all children in the study mounted antibody responses greater than the long term protective anti-PRP level of $>\mathbf{1 . 0}$ $\mu \mathrm{g} / \mathrm{ml}$. This protective level was, however, derived from field studies of the Hib vaccine in normal individuals, ${ }^{15}$ and no equivalent protection data exist for immunodeficient individuals. It is therefore not clear whether the higher titre of antibody mounted by the children with $\mathrm{HbSC}$ is clinically relevant to protection. It is also not clear whether this higher level may be associated with prolonged persistence of antibody and this aspect of the immune response to PRP-T is the subject of ongoing study.

Of the children with a diagnosis of sickle cell disease who are over the age of 2 years and have not received $\mathrm{Hib}$ vaccines, up to one half may have an antibody level below that indicating long term protection. Such children make a vigorous antibody response to a single dose of
PRP-T vaccine and hence we suggest that unimmunised individuals in this group should receive a single dose of a $\mathrm{Hib}$ conjugate vaccine, and this recommendation should be included in the indications for Hib vaccination. All infants born in the UK, including those with sickle cell disease, should receive three doses of Hib conjugate vaccines as part of the routine infant immunisation schedule.

We would like to thank all the staff of the Diagnostic Unit Queen Elizabeth Hospital Hackney for help with this study, and Christina Panagiotidi for technical help.

1 Overturf GD, Selzer JW, Chan L, et al. Pneumococcal polysaccharide immunization of children with sickle cell disease. II. Serologic response and pneumococcal disease following immunization. Am $₹$ Pediatr Hematol Oncol 1982; 4:25-35.

2 John AB, Ramlal A, Jackson H, Maude GH, Waight Sharma $A$, Serjeant GR. Prevention of pneumococcal infection in children with homozygous sickle cell disease. $B M$ F 1984;288:1567-70.

3 Wong WY, Powars DR, Chan L, Hiti A, Johnson C, Overturf G. Polysaccharide encapsulated bacterial infection in sickle cell anemia: a thirty year epidemiologic experience. Am f Hematol 1992;39:176-82.

4 Topley JM, Cupidore L, Vaidya S, Hayes RJ, Serjeant GR. Pneumococcal and other infections in children with sickle cell-hemoglobin C (SC) disease. $\mathcal{f}$ Pediatr 1982; 101:176-9.

5 Powars D, Overturf G, Turner E. Is there an increased risk of Haemophilus influenzae septicemia in children with of Haemophilus influenzae septicemia in chich
sickle cell anemia? Pediatrics 1983;71:927-31.

6 Buchanan GR, Smith SJ, Holtkamp CA, Fuseler JP. Bacterial infection and splenic function in children with hemoglobin SC disease. Pediatrics 1983;72:93-8.

7 Powars D, Overturf GD, Wilkins J. Infections in sickle cell and SC disease. $F$ Pediatr 1983;103:242-4.

8 Chilcote RR, Dampier C. Overwhelming pneumococcal septicemia in a patient with HbSC disease and splenic dysfunction. $\mathcal{F}$ Pediatr 1984;104:734-6.

9 Rubin LG, Voulalas D, Carmody L. Immunization of children with sickle cell disease with Haemophilus influenzae type b polysaccharide vaccine. Pediatrics 1989; 84:509-13.

10 Booy R, Taylor SA, Dobson SRM, et al. Immunogenicity and safety of PRP-T conjugate vaccine given according to and safety of PRP-T conjugate vaccine given according to the British accelerated

11 CDSC. Invasive Haemophilus influenzae infections: changing patterns. Communicable Disease Report 4 1994;48:227.

12 American Academy of Pediatrics. Red book: report of the Committee on Infectious Diseases. Elk Grove Village, Illinois American Academy of Pediatrics, 1994.

13 Department of Health. Immunisation against infectious disease. London: HMSO, 1992:100-4

14 Goldblatt D, Fairley CK, Cartwright K, Miller E. Interchangeability of conjugated Haemophilus influenzae type $b$ vaccines during the primary immunisation of infants at 2,3 and 4 months. $B M \mathscr{F} 1996 ; 312: 817-8$.

15 Käyhty H, Peltola H, Karanko V, Mäkelä P. The protective level of serum antibodies to capsular polysaccharide of Haemophilus influenzae type b. $f$ Infect Dis 1983; 147:1100-3.

16 Lane PA, O'Connell JL, Rogers ZR. Splenic dysfunction in sickle-hemoglobin C disease. Blood 1992;80:10a.

17 Lane PA, Rogers ZR, Woods GM, et al. Fatal pneumococcal septicemia in hemoglobin SC disease. $\mathcal{F}$ Pediatr 1994 124:859-62.

18 Käyhty H, Eskola J, Peltola $\mathrm{H}$, et al. Antibody responses to four Haemophilus influenzae type $b$ conjugate vaccines. Am $\mathcal{F}$ Dis Child 1991;145:223-7.

19 Sarnaik S, Kaplan J, Schiffman G, Bryla D, Robbins JB, Schneerson $R$. Studies on pneumococcus vaccine alone or mixed with DTP and on pneumococcus type $6 B$ and Haemophilus influenzae type $b$ capsular polysaccharidemophilus influenzae type $\mathrm{b}$ capsular polysaccharidewith sickle cell anemia. Pediatr Infect Dis $\mathcal{f} 1990 ; 9: 181-6$.

20 Rubin LG, Voulalas D, Carmody L. Immunogenicity of Haemophilus influenzae type b conjugate vaccine in children with sickle cell disease. Am $f$ Dis Child 1992;146:340-2.

21 Frank AL, Labotka RJ, Rao S, et al. Haemophilus influenzae type $b$ immunization of children with sickle cell diseases. Pediatrics 1988;82:571-5.

22 Marcinak JF, Frank AL, Labotka RL, et al. Haemophilus influenzae type $B$ vaccine in children with sickle cell disease: antibody persistence after vaccination at age one and one-half to six years. Pediatr Infect Dis $\mathcal{f}_{1991}$ 10:157-9. 